Vol. 9(14), pp. 1113-1123, 3 April, 2014

DOI: $10.5897 / A J A R 2013.7336$

Article Number: EF5416243685

ISSN 1991-637X

Copyright (C2014

African Journal of Agricultural

Author(s) retain the copyright of this article

Research

http://www.academicjournals.org/AJAR

\title{
Structure-related properties of sweetpotato critically impact the textural quality of fried chips
}

\author{
Ming Gao ${ }^{1 *}$, Juliet Huam², Claire Moallic ${ }^{3}$, Glory M. Ashu², Qun Xia ${ }^{2}$, Lakeisha Stewart ${ }^{2}$, \\ Victor $\mathrm{Njiti}^{2}$, Martha James ${ }^{4}$, Guoquan $\mathrm{Lu}^{5}$ and Deepak Bhatnagar ${ }^{6}$ \\ ${ }^{1}$ Cooperative Agricultural Research Center, Prairie View A\&M University, P. O. Box 519, MS 2008, Prairie View, \\ Texax 77446, USA. \\ ${ }^{2}$ Center for Biotechnology and Genomics, Alcorn State University, 1000 ASU Drive, Lorman, MS 39096, USA. \\ ${ }^{3}$ Tereos Syral, Burchtstraat 10, 9300 Aalst, Belgium. \\ ${ }^{4}$ Department of Biochemistry, Biophysics and Molecular Biology, lowa State University, Ames, IA 50011, USA. \\ ${ }^{5}$ Institute of Root and Tuber Crops, Zhejiang A\&F University, Lin'An, Hangzhou, Zhejiang 311300, P.R. China. \\ ${ }^{6}$ Food and Feed Safety Research Unit, USDA-ARS, 1100 Roberte Lee Blvd. New Orleans, LA 701246, USA.
}

Received date 6 May, 2013; Accepted 10 January, 2014

\begin{abstract}
This study sought to define what attributes of sweetpotatoes are most critical to textural qualities of their fried chips for effective selection of specialty cultivars. It compared texture-predicting fracturability of fried chips prepared from either structurally intact or disrupted slices of 13 cultivars; analyzed major attributes of these sweetpotatoes, including starch contents and properties, dry matter contents, and structure-related penetration resistances (measured using an adapted penetration test); and evaluated correlational relationships between these attributes of sweetpotatoes and fracturability of fried chips. The study found that lower dry matter (<22.6\% F.W.) and starch contents $(<10 \%$ F.W.), and lower gelatinization temperatures of starch in sweetpotatoes generally resulted in a more favorable fracturability (lower peak break force) of fried chips. However, contrary to potato, total dry matter content is not the sole determinant of textural qualities of fried sweetpotato chips; instead, structurerelated attributes of sweetpotatoes appear to have a greater impact. Partial structural disruptions of sweetpotato slices by blanching effectively improved fracturability of fried chips in all analyzed cultivars, and by $\sim 40 \%$ in eight of the 13 cultivars. Furthermore, the degree of structural penetrability of sweetpotatoes, as indexed by penetration resistances, showed very significant correlations with fracturability of fried chips.
\end{abstract}

Key words: Sweetpotato chips, fracturability, puncture test, structure-related attributes, dry matter content, starch.

\section{INTRODUCTION}

Sweetpotato [Ipomoea batatas (L.) Lam.] is the seventh largest food crop in world production (FAOSTAT, 2010).
It has many favorable agronomic attributes such as a short production cycle, tolerance of low soil fertility, and

*Corresponding author. E-mail: migao@pvamu.edu, Tel: (936)-261-2519. Fax: (936)-261-9975.

Author(s) agree that this article remain permanently open access under the terms of the Creative Commons Attribution License 4.0 International License 
resistance to many production stresses (Kays, 2005; Ravi and Indira, 1998). Furthermore, sweetpotato storage roots offer excellent nutrition and health benefits due to the presence of abundant vitamins (Vitamin A precursor $\beta$-Carotene, Vitamin B1 and $C$, and one of the few non-fat sources of Vitamin $E$ ), antioxidant micronutrients, beneficial complex carbohydrates, minerals and dietary fibers (Bovell-Benjamin, 2007; Woolfe, 1993). Despite such benefits, utilization of sweetpotatoes for food and industrial raw materials has steadily declined in recent years, and this is mirrored by reduction of its annual worldwide production from a peak of $\sim 1.5 \times 10^{8} \mathrm{t}$ in 1978 to $\sim 1.06 \times 10^{8}$ t in 2006 and thereafter (FAOSTAT, 1961 to 2010 ).

Although annual production of sweetpotatoes in the U.S. rose from $\sim 6.25 \times 10^{5} \mathrm{t}$ in 2000 to $\sim 1.08 \times 10^{6} \mathrm{t}$ in 2010 (FAOSTAT), it is still a greatly underutilized and undervalued crop. The average annual per capita consumption of sweetpotatoes from 2000 to 2010 in the U.S. was a meager $\sim 2.1 \mathrm{~kg}$, about 30 times lower than the annual $\sim 58.0 \mathrm{~kg}$ per capita consumption of potato (2010 Vegetable and Melon Year book, ERS-USDA). This low consumption, which both reflects and results in low demand and low commercial value for sweetpotatoes, can be largely attributed to its poor utilization in popular food products that have massmarket appeal, and its lack of use in large industrial applications. Recent efforts to increase sweetpotato consumption and commercial value have led to increased utilization of sweetpotatoes or their processed products, including flour, puree, and frozen cooked products, for making popular food items such as bread with up to $65 \%$ sweetpotato flour, ready-to-eat breakfast cereals, bread puddings, casseroles, tarts, muffins, pancake mixes, snack food items (chips, french-fries and flakes) and beverages (Bovell-Benjamin, 2007; Padmaja, 2009). Some of these products, in particular, sweetpotato chips and fries, are now gaining popularity, and are being commercially produced by several large U.S. companies, including the Terra Chip brand from the Hain Celestial Group Inc. of Colorado, the Seneca Foods Corporation of New York, Utz Quality Food of Pennsylvania, the Pringles brand from Proctor and Gamble, the Route 11 Potato Chips of Virginia, Zapp's Potato Chips of Louisiana and Lamb Weston of Washington. However, sweetpotato chips and fries made from common cultivars were viewed to have less satisfactory taste and texture relative to similar products made from potato (Collins, 1993; Woolfe, 1993).

The common U.S. sweetpotato cultivars that were developed primarily for fresh markets are not entirely suitable for the manufacture of chips and fries, despite recent improvement of production technology ( $\mathrm{Da}$ Silva and Moreira, 2008). Selection of novel specialty sweetpotato cultivars for making chips or fries with better textural qualities may help to sustain or enlarge their market shares.To define what attributes of sweetpotatoes are most critical to textural qualities of their fried chips for effective selection of such specialty cultivars, we investigated impacts of several major attributes of sweetpotatoes on texture-predicting fracturability (Bourne, 2002; Segnini et al., 1999a, b) of their fried chips.

\section{MATERIALS AND METHODS}

\begin{abstract}
Plant materials
The sweetpotato breeding and genetics program of North Carolina State University kindly provided sweetpotatoes of 10 cultivars (Covington, Carolina Rose, Hernandez, Porto Rico, Diane, O' Henry, Hannah, NC-Japanese, Hi-Dry and Suwon-122) from the 2007 growing season, and their dry matter contents. Two additional cultivars (Beauregard and Jewel) examined in 2007, all the twelve cultivars in 2008, and the twelve cultivars plus Zhenghong-3 (Accession PI 606266) for evaluation of chip textures and all other cultivars for penetration tests in 2010 were grown under recommended conditions (Mississippi State University Extension Service,http://msucares.com/lawn/garden/vegetables/list/sweetpotat o.html) at the Experimental Farm of Alcorn State University, Mississippi. The seeding plants of Zhenghong-3 and all other cultivars (excluding those cultivars from North Carolina State University) were initially obtained from the USDA-ARS Plant Genetic Resources Conservation Unit, Griffin, GA. All sweetpotatoes used in the study were not cured, and were not over one month in storage.
\end{abstract}

\section{Measurement of the dry matter content}

The dry matter content of sweetpotatoes was measured as completely dried weight per $100 \mathrm{~g}$ of slices randomly sampled out of $1 \mathrm{~kg}$ of sliced whole sweetpotatoes of representative sizes in triplicate, according to the standard method (Rodriguez, 1999). The reported dry matter contents of sweetpotatoes from the 10 cultivars that were initially provided by the North Carolina State University in 2007 are averages of the data from samples of the 2007 North Carolina and the 2010 Mississippi crops. The dry matter contents of the Zhenghong-3, Beauregard and Jewel sweetpotatoes are averages of triplicate sample measurements of the 2010 Mississippi crop.

\section{Measurements of the total starch content}

Fresh sweetpotato slices of $50 \mathrm{~g}$ randomly taken out of $1 \mathrm{~kg}$ slices of several whole sweetpotatoes of representative sizes were freeze-dried, ground using a coffee grinder and sieved to obtain fine dry powders $(<0.5 \mathrm{~mm})$. The total starch content of a $100 \mathrm{mg}$ dry sweetpotato powder sample was measured using a total starch assay kit (Megazyme International Ireland Ltd, Ireland), and normalized on a fresh-weight basis. The procedure recommended for samples containing resistant starch and soluble sugar was followed for all measurements. Triplicate measurements for all cultivars except Zhenghong-3 were made from two samples from the $2007 \mathrm{crop}$, and one from the $2008 \mathrm{crop}$. Measurements for the Zhenghong- 3 sweetpotatoes were made with three samples from the 2010 crop.

\section{Purification of starch and analyses of starch properties}

About $\sim 20 \mathrm{~g}$ sweetpotato slices randomly taken out of $1 \mathrm{~kg}$ slices of 
several whole sweetpotatoes of representative sizes were further chopped and finely ground in cold water $\left(1 \mathrm{ml} \mathrm{H}_{2} \mathrm{O}\right.$ per gram of tissue) using a Warring® Chopper/Grinder. Starch in the slurry was filtered through two layers of Miracloth into a $250 \mathrm{ml}$ beaker, and allowed to settle for $30 \mathrm{~min}$ or so. The settled starch was recovered, re-suspended in $\sim 30 \mathrm{ml}$ of cold water, and transferred to a centrifuge tube. Starch was pelleted by centrifugation for $5 \mathrm{~min}$ at $6,000 \mathrm{~g}$. Gel-like materials overlaying the packed white starch granules were scrapped using a spatula. Starch was then washed twice in a cold buffer $(62.5 \mathrm{mM}$ Tris- $\mathrm{HCl}, \mathrm{pH} 6.8 ; 10 \mathrm{mM}$ EDTA and $40 \mathrm{~g} \mathrm{~kg}^{-1}$ SDS), three times in cold water, and once in cold acetone $(\sim 15 \mathrm{ml})$ by repeated re-suspension and centrifugation. The purified starch was air dried, and stored in a sealed tube at $-20^{\circ} \mathrm{C}$. The purified starch samples of 20 to $25 \mathrm{mg}$ (measured to the nearest $0.1 \mathrm{mg}$ ) were used for analyses of the amylose content using the Megazyme Amylose/Amylopectin assay kit. Multiple measurements $(\geq 3)$ for all cultivars except Zhenghong-3 were made from independent samples from the 2007 and 2008 crops. Measurements for Zhenghong-3 were made from three samples from the 2010 crop.The gelatinization and retrogradation temperatures of all starch samples were determined by standard Differential Scanning Calorimetry (DSC).

\section{Preparation of sweetpotato chips}

Sweetpotatoes of 8.0 to $8.5 \mathrm{~cm}$ in diameter selected from each cultivar were lightly peeled, and had narrower ends cut off for size uniformity. The peeled and trimmed sweetpotatoes were sliced transversely into round pieces of $\sim 1 \mathrm{~mm}$ in thickness using a Chef's Choice 632 slicer with a serrated blade. About 100 or 200 slices of diameters 8.0 to $8.5 \mathrm{~cm}$ were randomly sampled out of $\sim 1 \mathrm{~kg}$ slices for each cultivar, and processed for texture measurements. Half of the sweetpotato slices from each cultivar were washed and soaked in ice water for at least $1 \mathrm{~h}$, blot-dried and fried for chips as the unblanched control. The other half of the slices were soaked in ice water briefly, drained, blanched in slightly acidic and salty boiling water ( $\sim 50 \mathrm{ml} \mathrm{l}^{-1}$ white vinegar and $4 \mathrm{~g} \mathrm{l}^{-1}$ table salts) for $3 \mathrm{~min}$, snap-chilled in ice water for 5 min or so, dried on racks in a drying oven for $1 \mathrm{~h}$ at $30^{\circ} \mathrm{C}$ and at room temperature for another $3 \mathrm{~h}$, flattened and frozen at $-20^{\circ} \mathrm{C}$ until ready for frying. Both blanched and unblanched slices were fried in Canola oil at $190^{\circ} \mathrm{C}$ for $1 \mathrm{~min}$, which were experimentally optimized for the best fracturability of chips from all the 13 cultivars.

During initial optimization, both blanched and unblanched slices from 23 cultivars or breeding lines were fried at two oil temperatures, 176 and $190^{\circ} \mathrm{C}$, to the extent of obvious partial burning (blackened, $<1 \%$ moisture by dry matter measurement). The peak break forces of these partially burned chips were measured, and regarded as the lowest (that is, the best or maximal fracturability) for the type of chips under the maximal frying time. Six of these cultivars whose slices needed shortest or longest frying times $\left(\sim 40 \mathrm{~s}\right.$ or $\sim 150 \mathrm{~s}$ at $\left.190^{\circ} \mathrm{C}\right)$ to reach partial burning were left out from further optimization and testing. Shorter frying times that would not significantly drop the best fracturability of chips were then sought for blanched and unblanched slices from some of the 17 cultivars or lines by frying in $190^{\circ} \mathrm{C}$ oil at 15 -s decremental time points from their maximal frying time.The condition of frying in $190^{\circ} \mathrm{C}$ oil for 1 min was found to yield chips having the best fracturability for both types of slices of 12 cultivars. But, it also resulted in certain degree of burning to chips from some of these cultivars (especially those having lower dry matter contents). This frying condition was adopted for preparing chips from these 12 cultivars, plus Zhenghong-3 at a later time for comparison.

\section{Fracture, puncture and penetration tests}

The fracture test for objective evaluation of textural properties of sweetpotato chips were performed essentially following the method of Segnini et al. (1999a, b), modified by the use of a custom-made cylinder holder ( 19.05 $\mathrm{mm}$ diameter) instead of a three-point support to overcome the surface-curling problem of the fried chips. A TMS-Pro texture analyzer (Food Technology Corporation, Virginia) equipped with a $100 \mathrm{~N}$ calibrated load cell, a $12.7 \mathrm{~mm}$ ball probe and the custom-made cylinder holder ( 19.05 mm diameter) was used for the test. A sweetpotato chip was placed on top of the cylinder holder with a nearly complete circular touch on the holder, and subjected to fracturing by the downward travelling ball probe. The ball probe was programmed to travel at a constant speed of 15 $\mathrm{mm}$ per min to a target displacement of $1 \mathrm{~mm}$ from where the load cell records a $0.5 \mathrm{~N}$ load. The peak load (that is, the maximum force of break) was quantified using a load versus displacement graph.

The penetration tests were performed using the TMS-Pro texture analyzer equipped with a $100 \mathrm{~N}$ calibrated load cell, TMS $3 \mathrm{~mm}$ diameter cylinder probe and a standard fixture table. Sweetpotatoes were either halved along the longitudinal root axis, or had both ends cut off transversely. Halved sweetpotatoes were placed on the fixture table with either the radial face down or up for the probe to puncture through the peripheral or radial face. The end-trimmed sweetpotato chunk was placed with one transverse face down on the fixture table for the probe to puncture parallel to the longitudinal root axis through the transverse face. The cylinder probe was programmed to travel at a constant speed of $250 \mathrm{~mm}$ per min to a target penetration displacement of $10 \mathrm{~mm}$ from where the load cell records a $0.5 \mathrm{~N}$ load. The average load for each $10 \mathrm{~mm}$ penetration was calculated from the load versus displacement graph. At least 50 individual penetrations of about 2 to $3 \mathrm{~mm}$ apart were made on each face for calculating the mean penetration resistance. The cylinder probe is small enough so that it only punctures a hole of about $3 \mathrm{~mm}$ in diameter on the testing surface, and causes no disruption of tissues 2 to $3 \mathrm{~mm}$ away from the hole.

\section{Statistical analyses}

The Prism 5 (GraphPad Software, La Jolla, CA) statistics and graphing software package was used for all statistical analyses.

\section{Preparation of microscopy slides}

Standard microtomy and microscopy procedures (Ruzin, 1999) were followed for preparation of paraffin-embedded sections of tissues (transverse and tangential sections), which were taken from blanched or unblanched sweetpotato slices, and for staining the sections with Toluidine Blue.

\section{RESULTS}

\section{Instrumental evaluation of the textural quality of sweetpotato chips}

The textural quality of fried sweetpotato chips was objectively evaluated via their mechanical fracturability, which was measured as the peak fracture force. As illustrated by load versus displacement curves from fracturing four sweetpotato chips (Figure 1), the peak loads registered the maximal forces of break, which were also the forces that caused the first major fractures characterized by a minimum of $10 \%$ load drop. These peak loads thus measure both hardness and brittleness of the chips. The peak loads have been demonstrated to 


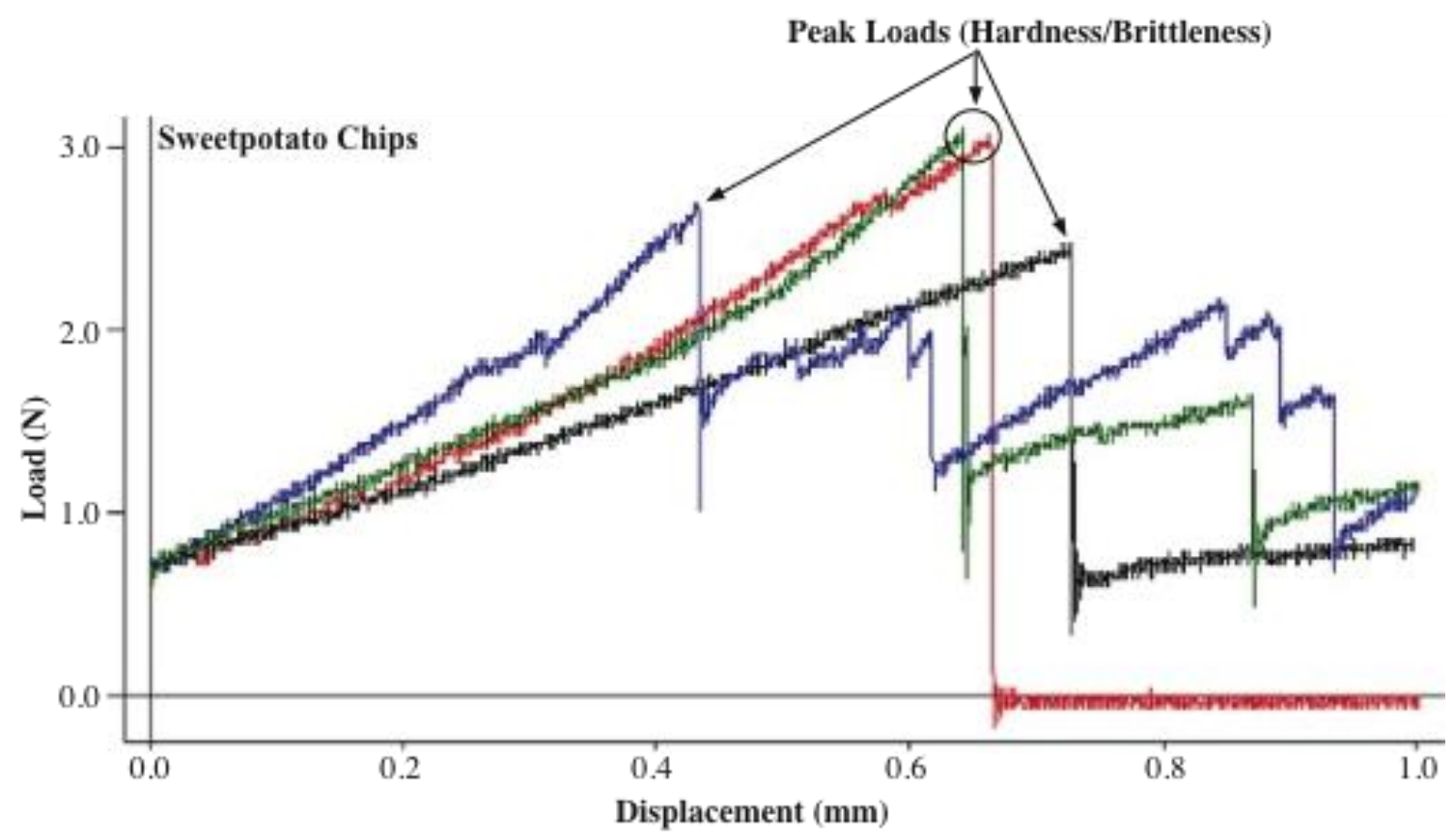

Figure 1. Illustration of typical load-displacement curves from fracture tests of fried sweetpotato chips. A sweetpotato chip was placed on top of a customer-made cylinder holder with a nearly complete circular touch on the holder, and subjected to fracturing by the downward travelling ball probe. The ball probe was programmed to travel at a constant speed of $15 \mathrm{~mm}$ per min to a target displacement of $1 \mathrm{~mm}$ from where the load cell records a $0.5 \mathrm{~N}$ load. Four load curves (in different colors) from fracture tests of 4 fried chips made from blanched slices of Covington sweetpotatoes are shown. The peak fracture loads registering the maximal forces of break and the forces causing the first major fracture marked by a 10\% load drop measure hardness and brittleness of the chips.

correlate tightly with (so as to predict) the sensorial textures of tenderness and crunchiness (Segnini et al., 1999a). The peak fracture force, which is the average of peak loads of 30 or more representative chips, should thus predict tenderness and crunchiness of sweetpotato chips. In other words, a larger peak fracture force indicating less favorable fracturability should predict less sensorial tenderness and crunchiness. All the chips from the 13 selected cultivars were fried to reach lowest levels of their respective peak fracture forces (or maximal fracturability, indicating maximally fried) so that residual moisture contents of these fried chips should have no impact on the comparison of chip fracturability. Since a uniform frying condition was used for all chips for the purpose of simplifying the comparison, chips from some of the cultivars (especially those with lower dry matter contents) did incur various degree of burning.

\section{Impacts of sweetpotato structure-related attributes on the textural quality of chips}

The impact of the storage-root tissue structure on the textural quality of fried sweetpotato chips was first assessed by comparing the fracturability of chips made from slices with or without structural disruption. Limited structural disruption was achieved mainly by blanching sweetpotato slices in acidic water with added salts. Microscopic analyses revealed that this treatment resulted in starch gelatinization and partially collapsed or broken cell walls in a cross-section of a blanched slice compared to a control slice, as well as separation or disruption of xylem elements in a tangential section of a blanched slice (Figure 2A). Furthermore, blanching under slightly acidic and salty conditions appeared to help fix the natural colors of sweetpotato slices. Blanched slices from all 13 cultivars, as compared with unblanched controls, yielded chips with a more favorable fracturability, and generally better appearance and less apparent retention of oil on the surface, as exemplified by those from the cultivar Hernandez in Figure 2B. As summarized in Figure 3 , the peak fracture forces of blanched chips from the 13 cultivars range from $1.96 \pm$ $0.48 \mathrm{~N}$ for Zhenghong-3's to $4.59 \pm 0.84 \mathrm{~N}$ for Suwon122 's, and those of unblanched chips range from $3.62 \pm$ $0.86 \mathrm{~N}$ for Zhenghong-3's to $5.12 \pm 0.82 \mathrm{~N}$ for Suwon122 's. The peak fracture forces of all these sweetpotato chips except that of blanched chips from Zhenghong-3 are much larger than those of a commercial brand of potato chips ranging from 0.75 to $2.00 \mathrm{~N}$, which predicts a much less favorable textural qualities of sweetpotato chips. The limited structural disruption by blanching 
Unblanched \& processed slices

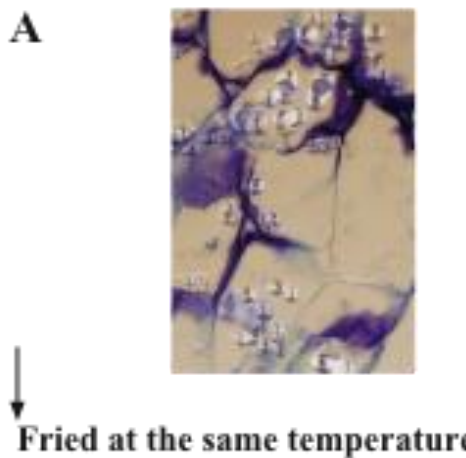

B

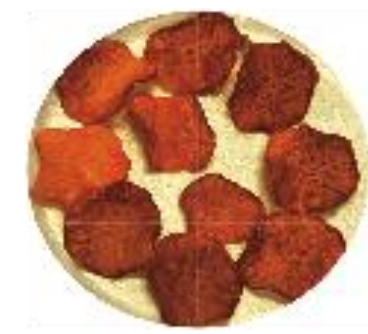

Blanched \& processed slices
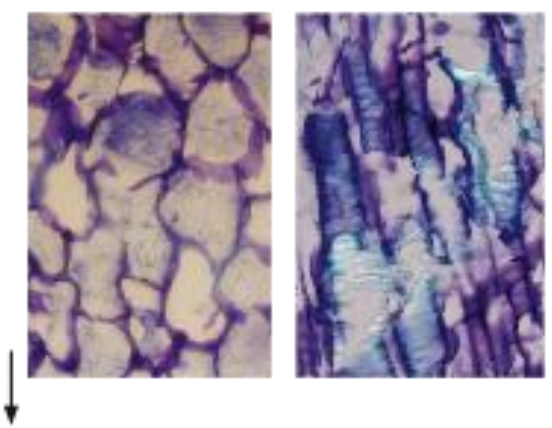

\section{Hernandez}

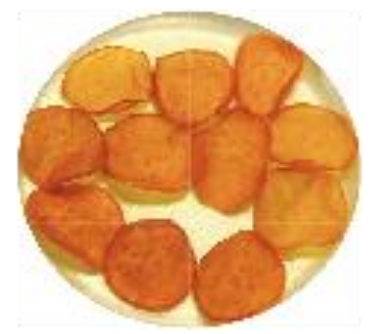

Figure 2. Illustration of the partial structural disruption in blanched sweetpotato slices and its effect on fried chips. To partially disrupt tissue structure, sweetpotato slices were blanched in slightly acidic and salty boiling water, snap-chilled, slowly dried, flattened and frozen before frying. The blanched and control slices were fried in oil at the same temperature $\left(190^{\circ} \mathrm{C}\right)$ for 1 min. (A) As compared with intact storage parenchyma cells on a cross section of an unblanched slice (left), corrupted or detached cell walls of storage parenchyma cells are evident on a cross section of a blanched slice (middle). In addition, corrupted or broken xylem elements can be seen on a tangential section of a blanched slice (right). The sections were stained with Toluidine Blue. (B) The lower panels shows appearances of representative fried chips made from unblanched and blanched slices of Hernandez sweetpotatoes.

reduced the peak fracture forces, or increased fracturability, of chips by an average of $\sim 40 \%$ for eight cultivars $(41.1 \%$ for Hernandez, $40.7 \%$ for Beauregard, $38.1 \%$ for Carolina Rose, $41.2 \%$ for Diane, $39.1 \%$ for Jewel, $43.0 \%$ for O' Henry, 39.5\% for Hannah and $45.9 \%$ for Zhenghong-3), by an average of $\sim 25 \%$ for three cultivars $(26.1 \%$ for Covington, $25.5 \%$ for Porto Rico and $21.5 \%$ for NC-Japanese), and to a lesser extent for two cultivars $(16.7 \%$ for $\mathrm{Hi}$-dry and $10.4 \%$ for Suwon122). Sweetpotatoes of the latter two cultivars both have high dry matter and starch contents relative to the other cultivars. The limited structural disruption could even bring the fracturability of blanched chips from Zhenghong-3 to a level that is comparable to that of commercial potato chips $(1.96 \pm 0.48 \mathrm{~N}$ versus 0.75 to $2.00 \mathrm{~N}$ peak fracture forces). This effective improvement of fracturability in blanched chips by limited structural disruption indicate that certain unfavorable structural attributes of sweetpotatoes are responsible for $\sim 25$ to $40 \%$ loss of fracturability, and thus loss of similar degrees of sensorial tenderness and crunchiness, in unblanched chips from 11 out of the 13 evaluated cultivars.

To further assess the impact of structural attributes of sweetpotatoes on textural qualities of fried chips, we attempted to quantify structural mechanical properties related to hardness, brittleness and firmness of sweetpotato tissues using an adapted puncture and penetration test. This test measures the tissue resistances against penetrations of a cylindrical probe over a target distance $(10 \mathrm{~mm})$ through the peripheral and radial faces of a longitudinal half of a sweetpotato, and through the transverse face of a transversely cut section to register the structural mechanical properties of a sweetpotato in both tangential and longitudinal directions.

As illustrated by the load versus displacement curves comparing the tests through peripheral faces of sweetpotatoes and potatoes from three and two cultivars, respectively (Figure 4A), clear distinctions of structural mechanical properties can be noted among the different types of sweetpotatoes, as well as between sweetpotatoes and potatoes. The average load over a 10 $\mathrm{mm}$ penetration calculated from the curve represents the local resistance along the penetration path. The average load from multiple puncture and penetration tests of a single sweetpotato sample or many sweetpotato samples 


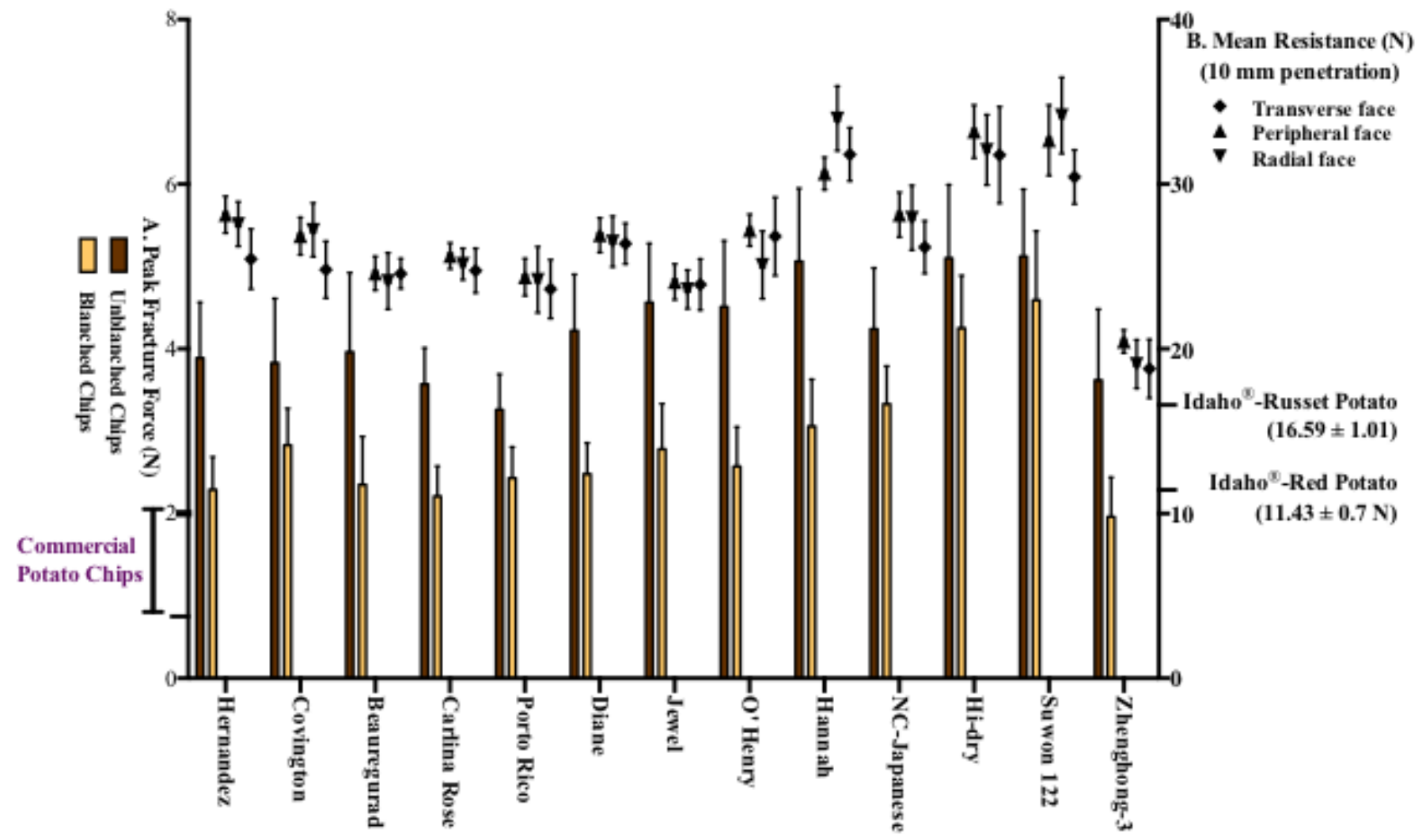

Figure 3. Comparisons of fracturability of fried chips from blanched and control sweetpotato slices of the 13 cultivars, and structurerelated mechanical attributes of these sweetpotatoes. A) Fracturability of fried sweetpotato chips were evaluated via the peak fracture forces measuring hardness and brittleness of fried chips (predicting their tenderness and crunchiness), which were calculated and averaged from load-displacement curves from fracture tests of fried chips (detailed in the text). The peak fracture forces $(\mathrm{N})$ of blanched (yellow bars) and unblanched chips (brown bars) from sweetpotatoes of the 13 cultivars were plotted against the left $Y$-axis. For comparison, the range of the peak fracture forces of potato chips from a commercial-brand is marked on the left Y-axis. B) Structure-related mechanical attributes of these selected sweetpotatoes were evaluated via the mean penetrations resistances $(\mathrm{N})$ through three faces (peripheral and radial faces of halved sweetpotatoes, and transverse face of end-trimmed chunks) using an adapted puncture and penetration test. The cylinder probe was programmed to travel at a constant speed of 250 $\mathrm{mm}$ per min to a target penetration displacement of $10 \mathrm{~mm}$ from where the load cell records a $0.5 \mathrm{~N}$ load. The average load for each $10 \mathrm{~mm}$ penetration was calculated from the load versus displacement graph. At least 50 individual penetrations of about 2 to $3 \mathrm{~mm}$ apart were made on each face for calculating the mean penetration resistance. The mean penetrations resistances ( $N$ ) through the three faces of sweetpotatoes from the 13 cultivars were plotted against the right $\mathrm{Y}$-axis. The mean penetration resistances perpendicular to the tuber axis through peripheral faces of the Idahol-Russet and Idahol-Red potatoes are marked on the right $Y$ axis for comparison. The error bars represent \pm 1 SD.

of the same cultivar has a narrow variability $(S D<5 \%$ of the mean), which makes this a sensitive test to distinguish sweetpotatoes of similar structure. The mean of more than 50 average loads taken from repeated punctures and penetrations covering a given area of a particular surface of a sweetpotato chunk is named the mean penetration resistance, which represents an average resistance against the movements of the probe (that is, shear stress) in a particular volume of sweetpotato tissues.

The mean penetration resistances are parameters related to sweetpotato structure, but not to size or developmental stage. As evidenced by the linear regression curve in Figure $4 B\left(r^{2}=0.3175\right)$, there were no statistically significant differences between the mean penetration resistances (through the peripheral face) of sweetpotatoes of seven size categories (34.7 to $86 \mathrm{~mm}$ maximal diameter, that is, up to the size of the US No. 1) from a breeding line. Thus, variations in the mean penetration resistances of similar sized sweetpotatoes from different cultivars can be expected to truly represent tissue structural differences of sweetpotatoes of these cultivars.

The triple penetration test was then used to discern texture-relevant structural differences of various sweetpotatoes for evaluating their impact on the textural qualities of fried chips. It was initially carried out on sweetpotatoes of 12 selected cultivars (excluding Zhenghon-3). Subsequent screening of 28 additional cultivars using the test identified the Zhenghong-3 


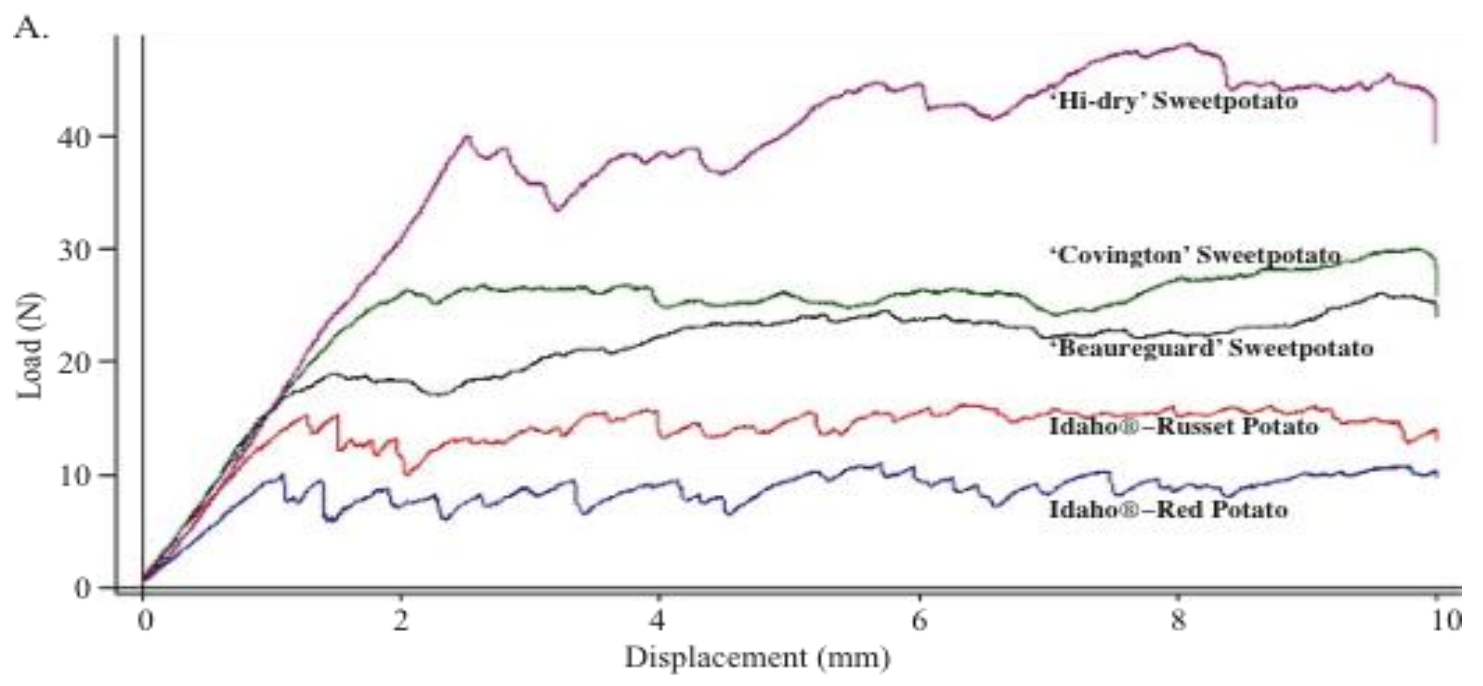

B.

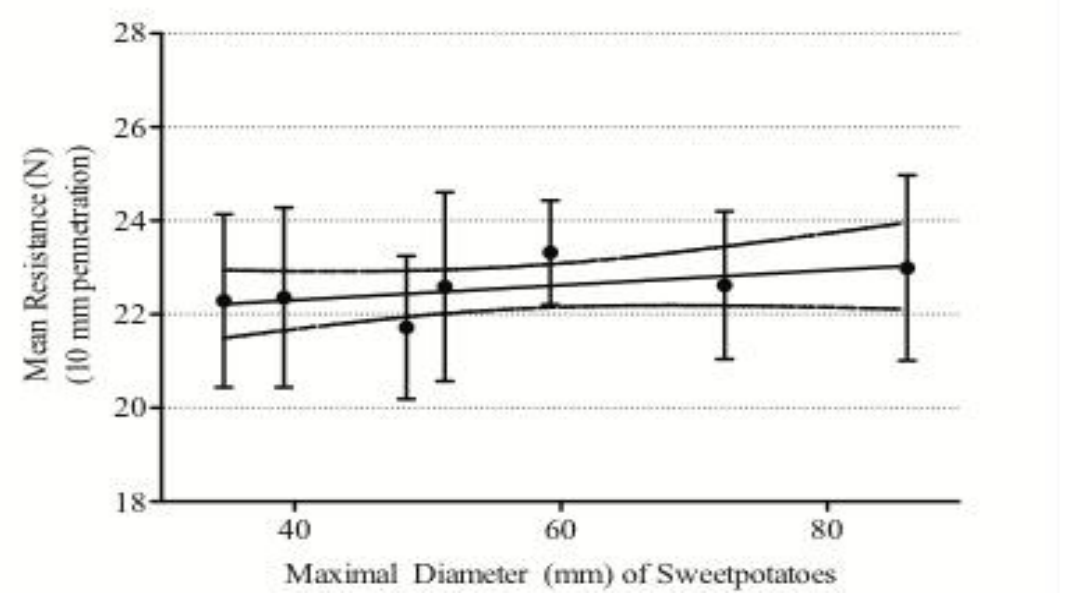

Figure 4. Demonstration of differentiation of structural differences of sweetpotatoes by the puncture and penetration test. A) Load-displacement curves of the penetration tests of sweetpotatoes of three cultivars, and potatoes of two cultivars. All five curves were recorded from penetrations perpendicular to the root or tuber long axis through peripheral face of sweetpotatoes or potato tubers. B) Linear regression curve of the mean penetration resistances (the mean of average loads of $\geq 50$ penetrations) of sweetpotatoes of a breeding line against their sizes. The mean penetration resistances of sweetpotatoes of various sizes do not differ significantly from one another $\left(r^{2}=0.3175\right)$.

sweetpotato as the one having the lowest mean penetration resistances in all three directions. The mean penetration resistances of sweetpotatoes from the 13 cultivars do not correlate with their dry matter or starch contents, which is consistent with its structure-dependent nature. Statistically significant differences among the mean penetration resistances of a sweetpotato through the three different faces were observed for some of the tested cultivars (Hernandez, Covington, O' Henry, Hannah, NC-Japanese, Suwon122, and Zhenghong-3), which may indicate a structural unevenness in these cultivars. However, this was not the case for many other tested cultivars (for example, Beauregard, Carolina Rose, Porto Rico, Diane, Jewel and Hi-dry), and may thus not be significant for breeding selection.

The mean penetration resistances through the peripheral face among the 13-sweetpotato cultivars range from $20.44 \pm 0.70 \mathrm{~N}$ for Zhenghong-3 to $33.19 \pm 0.1 .61 \mathrm{~N}$ for Hi-dry (Figure 3). As compared with $16.59 \pm 1.01 \mathrm{~N}$ for the Idaho $\circledast$-Russet potato and $11.43 \pm 0.70 \mathrm{~N}$ for the Idaho $\AA$-Red potato, these results indicate a harder, firmer and less brittle structure in sweetpotatoes than in potatoes. As summarized in Table 1, the mean penetration resistances of sweetpotatoes from the 13 cultivars through all three faces correlates very significantly $(P=0.002$ or 0.003$)$ or extremely significantly $(P<0.001)$ with the peak fracture forces of their unblanched chips $(r=0.775, P=0.002$, through 
Table 1. Major attributes of selected sweetpotato cultivars.

\begin{tabular}{llcccc}
\hline Cultivars & Flesh color & $\begin{array}{c}\text { Dry matter } \\
\left(\mathbf{g ~ k g} \mathbf{~}^{-1} \mathbf{F W}\right)\end{array}$ & $\begin{array}{c}\text { Total starch } \\
\left(\mathbf{g} \mathbf{~ k g}^{-1} \mathbf{F W} \mathbf{~ S D}\right)\end{array}$ & $\begin{array}{c}\text { Starch / dry } \\
\text { matter }(\%)\end{array}$ & $\begin{array}{c}\text { Amylose } \\
\left(\mathbf{g ~ k g} \mathbf{~}^{-1} \mathbf{s t a r c h} \pm \mathbf{S D}\right)\end{array}$ \\
\hline Hernandez & Deep orange & 193.2 & $82.3 \pm 1.0$ & 42.6 & $200.1 \pm 4.2$ \\
Covington & Orange & 194.4 & $69.4 \pm 3.5$ & 35.8 & $212.2 \pm 4.7$ \\
Beauregard & Orange & 198.2 & $76.7 \pm 6.2$ & 38.7 & $198.0 \pm 3.3$ \\
Carolina Rose & Orange & 202.1 & $102.7 \pm 7.7$ & 50.8 & $186.7 \pm 1.3$ \\
Porto Rico & Orange mottled & 206.4 & $156.0 \pm 7.9$ & 75.7 & $214.6 \pm 6.0$ \\
Diane & Dark orange & 209.2 & $93.6 \pm 5.9$ & 44.8 & $198.6 \pm 4.1$ \\
Jewel & Deep orange & 226.0 & $56.7 \pm 3.3$ & 25.1 & $181.1 \pm 3.2$ \\
O' Henry & Yellow & 229.0 & $139.6 \pm 1.1$ & 61.0 & $195.6 \pm 1.4$ \\
Hannah & Cream & 254.3 & $191.7 \pm 1.3$ & 75.5 & $181.1 \pm 3.2$ \\
NC-Japanese & White & 296.4 & $173.5 \pm 4.1$ & 58.6 & $207.7 \pm 0.8$ \\
Zhenghong-3 & Yellow cream & 300.2 & $173.7 \pm 2.9$ & 57.9 & $294.3 \pm 3.8$ \\
Hi-dry & Cream & 306.3 & $273.1 \pm 16.8$ & 89.3 & $215.7 \pm 2.6$ \\
Suwon 122 & Yellow & 356.0 & $301.8 \pm 10.4$ & 84.8 & $295.2 \pm 5.2$ \\
\hline
\end{tabular}

peripheral face; $r=0.759, P=0.003$, through radial face; and $r=0.828, P<0.001$, through transverse face). Similar results were seen for the blanched chips $(r=0.844$, $\mathrm{P}<0.001$, through peripheral face; $r=0.807, \mathrm{P}<0.001$, through radial face; and $r=0.771, P=0.002$, through transverse face). This suggests that sweetpotato structural attributes defining hardness, brittleness and firmness should be a primary determinant of the fracturability (also sensorial tenderness and crunchiness) of their fried chips, which is consistent with the results from the partial structural disruption test.

\section{Impacts of sweetpotato dry matter contents, and starch contents and properties on the texture of their fried chips}

Next, we investigated impacts of the dry matter content, and the total amount, composition and thermal properties of the starch in sweetpotatoes on the textural quality of fried chips. As summarized in Table 1, sweetpotatoes of various flesh colors from 13 selected cultivars have dry matter ranging from 193.2 to $356.0 \mathrm{~g} \mathrm{~kg}-1 \mathrm{FW}$, and total starch ranging from 56.7 to $301.8 \mathrm{~g} \mathrm{~kg}^{-1}$ FW. Sweetpotatoes from these selected cultivars provide six levels (shaded groups) of dry matter contents for evaluation. As summarized in Table 2, the dry matter and starch contents in sweetpotatoes from the 13 cultivars have a significant correlation with peak fracture forces of their unblanched fried chips $(r=0.589, P=0.034$ and $r=$ $0.580, P=0.038$, respectively), and a very significant correlation with those of their blanched fried chips $(r=$ $0.736, P=0.004 ; r=0.782, P=0.002$, respectively). This suggests that higher dry matter and starch contents in sweetpotatoes generally have negative impacts on textural qualities of fried chips. Moreover, the ratio of starch to dry matter contents in sweetpotatoes has a significant correlation with peak fracture forces of blanched chips $(r=0.623, P=0.023)$, but not with those of unblanched fried chips $(P=0.151)$. In other words, a higher starch percentage in the dry matter of sweetpotatoes causes an adverse impact on the fracturability (a higher peak break force) only in fried chips from blanched slices, in which the gelatinization of starch and partial structural disruption should have helped reduction of the peak break force. Thus, impacts of starch and dry matter content on textural qualities of fried chips may be secondary to those of relevant structural attributes as the adverse impact of a higher starch to dry matter ratio appeared to be masked in fried chips from structurally intact unblanched slices.Interestingly, the amylose contents of starch showed no significant correlation with peak fracture forces of unblanched and blanched sweetpotato chips ( $P$ $=0.919$ and 0.311 , respectively), and should thus have little impact on chip texture.

As shown in Table 3, a large variation of gelatinization temperatures was observed among 10 tested sweetpotato starch samples. The peak $\left(T_{p}\right)$ and conclusion $\left(T_{c}\right)$ gelatinization temperatures of these 10 starch samples showed significant correlation with the peak fracture forces of unblanched fried chips $(r=0.660$, $P=0.038 ; r=0.670, P=0.034$, respectively) made from sweetpotatoes of these 10 cultivars. It is likely that a lower $T_{p}$ and $T_{c}$ of sweetpotato starch allowed a greater degree of gelatinization of the starch in their derived chips under the frying conditions, and thus less hardness and greater brittleness of the chips. The gelatinization onset $\left(T_{0}\right)$ and $T_{c}$ of these 10 starch samples also showed significant correlation with the peak fracture forces of their blanched fried chips $(r=0.668, P=0.035$; $r=0.682, P=0.030$, respectively) made from these 
Table 2. Summary of correlation coefficients between major sweetpotato attributes and peak fracture forces of fried chips.

\begin{tabular}{|c|c|c|c|c|}
\hline \multirow[t]{2}{*}{ Parameter } & \multicolumn{2}{|c|}{$\begin{array}{l}\text { With peak fracture forces of } \\
\text { unblanched chips }\end{array}$} & \multicolumn{2}{|c|}{$\begin{array}{l}\text { With peak fracture forces of } \\
\text { blanched chips }\end{array}$} \\
\hline & Pearson $r$ & $\mathbf{P}$ & Pearson $r$ & $\mathbf{P}$ \\
\hline Dry matter content & 0.589 & 0.034 & 0.736 & 0.004 \\
\hline Total starch content & 0.580 & 0.038 & 0.782 & 0.002 \\
\hline Starch / dry matter & 0.422 & 0.151 & 0.623 & 0.023 \\
\hline Amylose content & 0.031 & 0.919 & 0.305 & 0.311 \\
\hline \multicolumn{5}{|c|}{ Starch gelatinization temperature } \\
\hline $\mathrm{T}_{0}$ & 0.591 & 0.072 & 0.668 & 0.035 \\
\hline $\mathrm{T}_{\mathrm{c}}$ & 0.670 & 0.034 & 0.682 & 0.030 \\
\hline$T_{p}$ & 0.660 & 0.038 & 0.586 & 0.075 \\
\hline \multicolumn{5}{|c|}{ Mean penetration resistances through } \\
\hline Peripheral face & 0.775 & 0.002 & 0.844 & $<0.001$ \\
\hline Radial face & 0.759 & 0.003 & 0.807 & $<0.001$ \\
\hline Transverse face & 0.828 & $<0.001$ & 0.771 & 0.002 \\
\hline
\end{tabular}

Table 3. Thermal analysis of gelatinization and retrogradation of starch from selected sweetpotato cultivars by differential scanning calorimetry (DSC).

\begin{tabular}{lcccccccc}
\hline \multirow{2}{*}{ Cultivars } & \multicolumn{4}{c}{ Gelatinization } & \multicolumn{4}{c}{ Retrogradation } \\
\cline { 2 - 9 } & $\mathbf{T}_{\mathbf{o}}\left({ }^{\circ} \mathbf{C}\right)$ & $\mathbf{T}_{\mathbf{p}}\left({ }^{\circ} \mathbf{C}\right)$ & $\mathbf{T}_{\mathbf{c}}\left({ }^{\circ} \mathbf{C}\right)$ & $\Delta \mathbf{H}(\mathbf{J} / \mathbf{g})$ & $\mathbf{T}_{\mathbf{o}}\left({ }^{\circ} \mathbf{C}\right)$ & $\mathbf{T}_{\mathbf{p}}\left({ }^{\circ} \mathbf{C}\right)$ & $\mathbf{T}_{\mathbf{c}}\left({ }^{\circ} \mathbf{C}\right)$ & $\Delta \mathbf{H}(\mathbf{J} / \mathbf{g})$ \\
\hline Hernandez & 55.3 & 64.5 & 61.7 & 2.9 & 52.7 & 66.5 & 59.6 & 0.8 \\
Covington & 60.6 & 81.5 & 66.3 & 10.0 & 51.2 & 63.9 & 59.9 & 0.9 \\
Beauregard & 64.4 & 81.3 & 71.5 & 13.3 & 51.8 & 65.2 & 59.6 & 2.9 \\
Porto Rico & 57.8 & 70.0 & 62.4 & 7.1 & 50.8 & 66.5 & 58.7 & 2.1 \\
Diane & 64.6 & 85.8 & 69.8 & 15.2 & 54.0 & 70.7 & 60.1 & 3.9 \\
O' Henry & 70.2 & 86.8 & 75.7 & 14.0 & 52.1 & 67.2 & 60.0 & 3.5 \\
Hannah & 60.3 & 80.3 & 68.5 & 12.3 & 52.3 & 67.4 & 60.2 & 1.7 \\
NC Japanese & 72.9 & 84.8 & 77.9 & 9.4 & 51.3 & 69.0 & 59.7 & 4.8 \\
Hi-dry & 69.7 & 89.5 & 74.2 & 12.6 & 52.2 & 66.6 & 59.7 & 2.5 \\
Suwon 122 & 73.0 & 87.1 & 80.1 & 12.2 & 51.6 & 67.6 & 60.0 & 3.8 \\
\hline
\end{tabular}

$\mathrm{T}_{0}, \mathrm{~T}_{\mathrm{p}}$ and $\mathrm{T}_{\mathrm{c}}$ : onset, peak, and conclusion gelatinization or retrogradation temperature $\left({ }^{\circ} \mathrm{C}\right) ; \Delta \mathrm{H}$ : enthalpy. Values are average of at least four measurements of starch samples from two crops grown at different locations during two seasons.

cultivars. A lower $T_{0}$ and $T_{c}$ may have favored a higher degree of gelatinization of the starch in blanched slices under the same blanching conditions, and thus less hardness and greater brittleness of their derived chips. The gelatinization enthalpy of starch from selected sweetpotato cultivars showed large differences $(2.9 \mathrm{~J} / \mathrm{g}$ for Hernandez starch to $15.2 \mathrm{~J} / \mathrm{g}$ for Diane starch), but no significant correlation with peak fracture forces of either unblanched or blanched chips. The thermal retrogradation properties among these starch samples, except the enthalpy, vary only within a narrow range, and have no significant correlation with the chip brittleness and hardness texture.

\section{DISCUSSION}

This study evaluated several major attributes of sweetpotatoes from 13 selected cultivars on textural qualities of their fried chips. The results indicates that sweetpotatoes having dry matter contents from 19 to $22.6 \%$ (F.W.), total starch lower than $\sim 10 \%$ (F.W.), low starch gelatinization temperatures similar to those in Covington and Hernandez sweetpotatoes, and tissue structural properties such as seen in the Zhenghong-3 sweetpotato could have the best potential for improved textural qualities of fried chips. The dry matter content in sweetpotatoes has a major impact on textural qualities of 
fried chips, but is not the sole determinant as in potato. Potatoes having dry matter contents of 21.7 to $25.1 \%$ with $22.7 \%$ as the optimum are best suited for making quality chips (Lisin'ska, 1989). In contrast, a dry matter content of $22.6 \%$ in sweetpotatoes seems to be the upper limit for making chips of appropriate fracturability. All the eight sweetpotatoes cultivars (Hernandez, Covington, Beauregard, Carolina Rose, Porto Rico, Diane, Jewel and O'Henry) having starch ( 57 to156 g kg $\left.{ }^{-1}\right)$ and dry matter $\left(\sim 193\right.$ to $\left.229 \mathrm{~g} \mathrm{~kg}^{-1}\right)$ contents lower than or within the range of the optimal values $\left(\sim 150\right.$ to $190 \mathrm{~g} \mathrm{~kg}^{-1}$, and 217 to $251 \mathrm{~g} \mathrm{~kg}^{-1}$, respectively) for potatoes best suited for making quality chips (Simmonds, 1977) also yielded chips with more favorable fracturability. On the other hand, sweetpotatoes having too low a dry matter content and high moisture may not be desirable either, as this could lead to higher retention of oil in fried chips (Hoover and Miller, 1973; Padmaja, 2009).

Compared to the compositional attributes, structurerelated attributes of sweetpotatoes seem to have a much greater impact on textural qualities of fried chips. This is evidenced by the effective improvement of chip fracturability through partial structural disruption before frying, and by a very significant correlation between increased structural penetrability in sweetpotatoes and better fracturability of their fried chips. Blanching (especially in lightly acidic water), surface-drying, and freezing and thawing have long being recognized to be a very effective way to reduce hardness and to improve the textural quality of fried sweetpotato chips (Padmaja (2009). These mostly physical treatments were shown in this study to partially disrupt tissue structures of sweetpotato slices, and to effectively improve fracturability (hence textural qualities) of fried chips. It is estimated that unfavorable structure-related attributes of sweetpotatoes might be responsible for $\sim 25$ to $40 \%$ reduction in fracturability (predicting similar extent of sensorial tenderness and crunchiness) of chips made from 11 out of 13 tested cultivars.

The relevance and importance of tissue structures to culinary texture have been well known for many fruits and vegetables, including potato tubers (Reeve, 1970). Although, the anatomical nature of sweetpotatoes as swollen roots has been long recognized, very few attempts have been made to understand impacts of their unique structural attributes on culinary textures. Some unique structural attributes of sweetpotatoes, such as thickness of the cambium ring and degree of its lignification, and the amount and dispersion patterns of xylem strands, can be expected to have significant impacts on their culinary textures. After all, sweetpotato storage roots are primarily consumed or used as a structured food item, rather than their individual chemical components.

It is, however, very difficult to directly quantify microscopic attributes of sweetpotato structures for statistical analyses of their impacts on culinary textures, or for breeding selection. Since culinary textures are sensorial experience derived from physical interactions or behaviors of cooked food items in the mouth, the mechanical expression of the sweetpotato tissue structure as a whole becomes functionally more relevant to culinary textures. The adapted puncture and penetration test quantify such structural mechanical attributes of sweetpotatoes that can be predicative of their culinary performance, and may thus be used as a rapid method to screen clones than may have desirable culinary performance. This study also showed that sweetpotato storage roots generally have a much less penetrable structure than potato tubers, which is consistent with the report that the hardness of sweetpotatoes is about two and half times more than that of potato (Yee et al., 2012). The relatively more penetrable structure in the Zhenghong-3 sweetpotato still had a penetration resistance (perpendicular to the root axis via peripheral face) of about $23 \%$ (20.44 \pm 0.70 versus $16.59 \pm 1.01 \mathrm{~N}$ ) more than that of the Idaho ${ }^{\circledR}$ Russet potato.

The flavor quality of sweetpotatoes has been argued to be the key to sweetpotato consumption, and has been included in quality evaluations in breeding programs (Kays, 2006; Kays and Wang, 2002). However, flavor as chemical interactions of food in the mouth is only one part of the mouth-feel of a food item. Many food quality attributes from physical interactions in the mouth such as fracturability and roughness are clearly related to tissue structures of uncooked food items (Reeve, 1970). Therefore, evaluation of tissue structures, especially using simple mechanical measurements, should be also included in quality evaluation of sweetpotatoes in breeding programs, especially those for breeding specialty cultivars best suited for certain food uses.

\section{ACKNOWLEDGEMENTS}

This work was supported by a grant (2007-38814-18467) to Ming Gao and a grant (2010-38863-21250) to the Center for Biotechnology and Genomics at Alcorn State University from the National Institute of Food and Agriculture (NIFA), United States Department of Agriculture. We would like to thank Dmitry Mylnikov for technical assistances.

\section{Conflict of Interests}

The author(s) have not declared any conflict of interests.

\section{REFERENCES}

Bourne MC (2002). Food texture and viscosity: concept and measurement. 2nd ed. Academic Press, San Diego, USA.

Bovell-Benjamin AC (2007). Sweet potato: A review of its past, present, and future role in human nutrition. In: Advances in Food and Nutrition Research (ed. Steve LT, Academic Press, New York) 52:1-59.

Collins WW (1993). Root vegetables: New uses for old crops. In: New 
crops (ed. Janick J, Simon J E, Wiley, New York, USA), pp. 533-537.

Da Silva PF, Moreira RG (2008). Vacuum frying of high-quality fruit and vegetable-based snacks. LWT - Food Sci. Technol. 41:1758-1767.

Hoover MW, Miller NC (1973). Process for producing sweetpotato chips. Food Technol. 27:74-80.

Kays SJ (2005). Sweetpotato production worldwide: Assessment, trends and the future. Acta Hort. (ISHS). 670:19-25.

Kays SJ (2006). Flavor- the key to sweetpotato consumption. Acta Hort. (ISHS) 703:97-106.

Kays SJ, Wang Y (2002). Sweetpotato quality: Its importance, assessment and selection in breeding. Acta Hort. (ISHS) 583:187193.

Lisin'ska G (1989). Manufacture of potato chips and french fries. In: Potato science and technology (ed. Lisin'ska G, Leszczyn'ski W, Elselvier Science, Essex, UK), pp. 166-227.

Padmaja G (2009). Uses and nutritional data of sweetpotato. In: The sweetpotato (ed. Loebenstein GT, Hottappilly G, Springer, Netherlands), pp. 189-234.http://dx.doi.org/10.1007/978-1-40209475-0 11

Ravi V, Indira P (1998). Crop physiology of sweetpotato. In: Horticultural reviews (ed. Janick J, Wiley-Blackwell, Hoboken, NJ, USA). 6:277338.

Reeve RM (1970). Relationships of histological structure to texture of fresh and processed fruits and vegetables. J. Texture Stud. 1:247284.http://dx.doi.org/10.1111/j.1745-4603.1970.tb00730.x

Rodriguez F (1999). Methods to evaluate culinary quality and other attributes for processing sweetpotato storage roots. In: Sweetpotato (Ipopoea batatas) germplasm management trainging manual (ed. Huaman Z, International Potato Center (CIP), Lima, Peru), pp. 1-17.

Ruzin SE (1999). Plant microtechnique and microscopy. Oxford University Press, New York, USA.PMid:9952452 PMCid:PMC32133
Segnini S, Dejmek P, Oste R (1999a). Relationship between instrumental and sensory analysis of texture and color of potato chips. J. Texture Stud. 30:677-690.http://dx.doi.org/10.1111/j.17454603.1999.tb00237.x

Segnini S, Dejmek P, Oste R (1999b). Reproducible texture analysis of potato chips. J. Food Sci. 64:309312.http://dx.doi.org/10.1111/j.1365-2621.1999.tb15889.x

Simmonds NW (1977). Relations between specific gravity, dry matter content and starch content of potato. Potato Res. 20:137140.http://dx.doi.org/10.1007/BF02360274

Woolfe J (1993). Sweetpotato - a versatile and nutritious food for all. In: Product development for root and tuber crops (ed. Scott GJ, et al., International Potato Center (CIP), Lima, Peru), pp. 221-232.

Yee LC, Mazlina MKS, Tuah BTH (2012). Relationship between selected properties of starchy vegetables on grating and slicing production rate. Am. J. Agric. Biol. Sci. 7:232238.http://dx.doi.org/10.3844/ajabssp.2012.232.238 